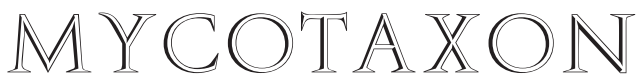

Volume 125, pp. 209-215

http://dx.doi.org/10.5248/125.209

July-September 2013

\title{
Two new species of Repetophragma from the Iberian Peninsula
}

\author{
Rafael F. Castañeda-Ruiz ${ }^{1}$, Margarita HernándeZ-Restrepo ${ }^{2}$, \\ Josepa Gené ${ }^{2}$, Milagro Granados ${ }^{3} \&$ Josep Guarro $^{2}$ \\ ${ }^{1}$ Instituto de Investigaciones Fundamentales en Agricultura Tropical 'Alejandro de Humboldt' (INIFAT), \\ Académico Titular de la "Academia de Ciencias de Cuba", \\ Calle 1 Esq. 2, Santiago de Las Vegas, C. Habana, Cuba, C.P. \\ ${ }^{2}$ Unitat de Micologia, Facultat de Medicina Ciències de la Salut, Universitat Rovira $i$ Virgili, \\ 43201 Reus, Spain \\ ${ }^{3}$ Centro de Investigaciones en Protección de Cultivos (CIPROC), Universidad de Costa Rica \\ *Correspondence To: josepa.gene@urv.cat
}

\begin{abstract}
AвSTRACT - Repetophragma fragile and R. ibericum, two new microfungi collected on plant debris, are described and illustrated. Repetophragma fragile is distinguished by variable, subnavicular, obovoid to subrhomboidal, collapsing, 0 -1-septate, pale brown conidia often with faint bands or irregular spots on the surface. Repetophragma ibericum is characterized by turbinate to globose, mostly 2 -septate, guttulate conidia, with brown central cell and paler brown end cells.
\end{abstract}

Key wORDs - asexual fungi, systematics, litter

Repetophragma Subram. was erected to accommodate Sporidesmium species with euseptate conidia produced on monoblastic, integrated, indeterminate conidiogenous cells with several percurrent extensions (Subramanian 1992). Castañeda-Ruiz et al. (2011) provided an illustrated update and key to Repetophragma species, adding another species and making twelve new combinations. During two field expeditions in Spain (to Burgos, 2010) and Portugal (to Minho province, 2011), more than 300 samples of dead plant material colonized by anamorphic fungi were collected. Plant debris was treated according to Castañeda-Ruiz (2005) and examined periodically under the stereomicroscope for a 2-month period. Semi-permanent and permanent microscope slides of fungi growing on the natural substrate were mounted in lactic acid $85 \%$ and polyvinyl alcohol and examined under the light microscope. Photomicrographs were obtained with a Zeiss AXIO Imager M1 light microscope (Göttingen, Germany). Among these 300 samples two 
undescribed Repetophragma species were collected, which are herein described and illustrated.

\section{Taxonomy}

Repetophragma fragile R.F. Castañeda, Hern.-Rest., Gené \& Guarro, sp. nov. MycoBank MB802412

Differs from Repetophragma biseptatum by having variable, fragile, very often collapsed, $0-1$-septate, pale brown conidia, sometimes with faint bands or irregular spots on the surface.

TyPE: Spain, Burgos, Salas de los Infantes, Rio Pedroso, $42^{\circ} 04^{\prime} \mathrm{N} 3^{\circ} 18^{\prime} \mathrm{W}$, on submerged decaying wood of unidentified plant, 10 November 2010, coll. M. Hernández-Restrepo \& J. Gené C10/126 (Holotype, CBS H-20750; Isotype, FMR 11581).

ЕтумоцоGy: Latin, fragile, referred to the delicate, very often collapsed conidia.

Colonies on the natural substrate effuse, hairy, brown. Mycelium superficial and immersed, composed of septate, branched, brown, smooth hyphae 1-2.5 $\mu \mathrm{m}$ diam. Conidiophores distinct, single, erect, straight or slightly geniculate toward the apex, 6-12-septate, with 4-8 annellations near the apex, 87-190 $\times 5-10 \mu \mathrm{m}$, smooth, brown at the base and pale brown toward the apex. Conidiogenous CELls monoblastic, terminal, integrated, 5-20 × 5-8 $\mu \mathrm{m}$, indeterminate, annellidic with numerous cyathiform enteroblastic percurrent extensions. Conidial secession schizolytic. Conidia solitary, variable, subnavicular, obovoid, mucronate to somewhat acute, long sub-rhomboidal, fragile, very often collapsed, 0 -1-septate, pale brown, but sometimes with faint bands or irregular spots, slightly obscure or brown pigmented on the surface, 25-42 × 10-17 $\mu \mathrm{m}$, truncate, 5-7.5 $\mu \mathrm{m}$ wide at the base, smooth-walled, dry. Teleomorph unknown.

Repetophragma fragile superficially resembles $R$. biseptatum (M.B. Ellis) Subram. (Subramanian 1992, Castañeda-Ruiz et al. 2011), but R. biseptatum produces navicular, 3-septate, smooth-walled conidia with brown to dark brown upper cells and subhyaline basal cell, 17-23 $\times 7-8 \mu \mathrm{m}$ and cannot be confused with $R$. fragile.

Repetophragma ibericum R.F. Castañeda, Hern.-Rest., Gené \& Guarro, sp. nov.

MrcoBank MB802415

FIGS 3, 4

Differs from Repetophragma quadriloculare by its globose to subturbinate, mostly 2septate conidia, with dark brown or brown central cell and pale brown end cells.

Type: Portugal, Minho province, "Lagoas de Bertiandos", $41^{\circ} 46^{\prime} \mathrm{N} 8^{\circ} 38^{\prime} \mathrm{W}$, on bark of Eucalyptus globulus Labill, 9 November 2011, R.F. Castañeda, M. Hernández- Restrepo, J. Gené \& J. Mariné-Gené C11/55 (Holotype, HAL 2452 F; Isotype, FMR 12183).

ЕтумоцоGy: Latin, ibericum, in reference to Iberian Peninsula. 
Repetophragma spp. nov. (Iberian Peninsula) ... 211

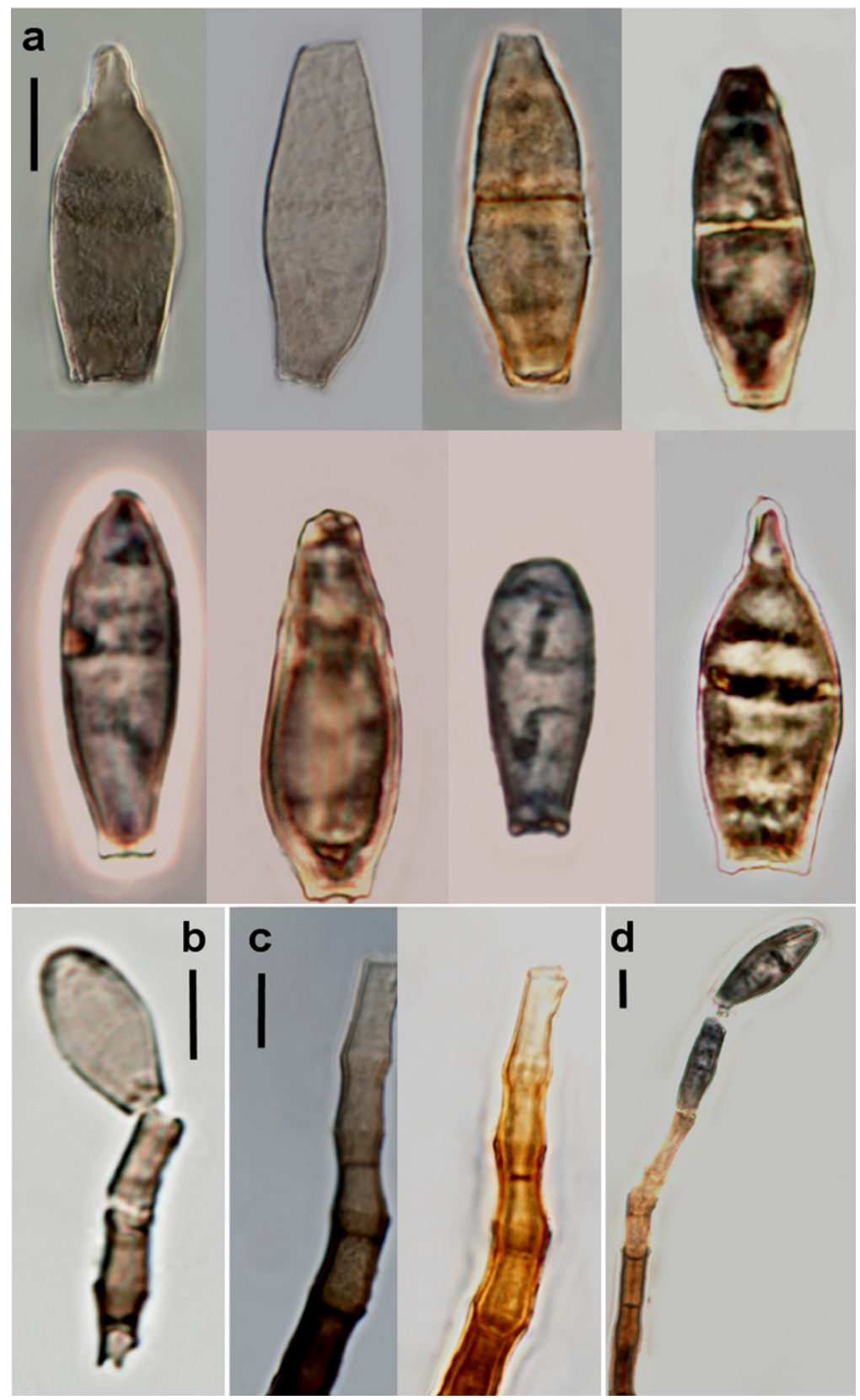

FIG. 1. Repetophragma fragile (ex holotype CBS H-20750):

a. Conidia. b, d. Conidiogenous cells and conidia. c. Conidiogenous cells. Bars $=10 \mu \mathrm{m}$. 
212 ... Castañeda-Ruiz \& al.

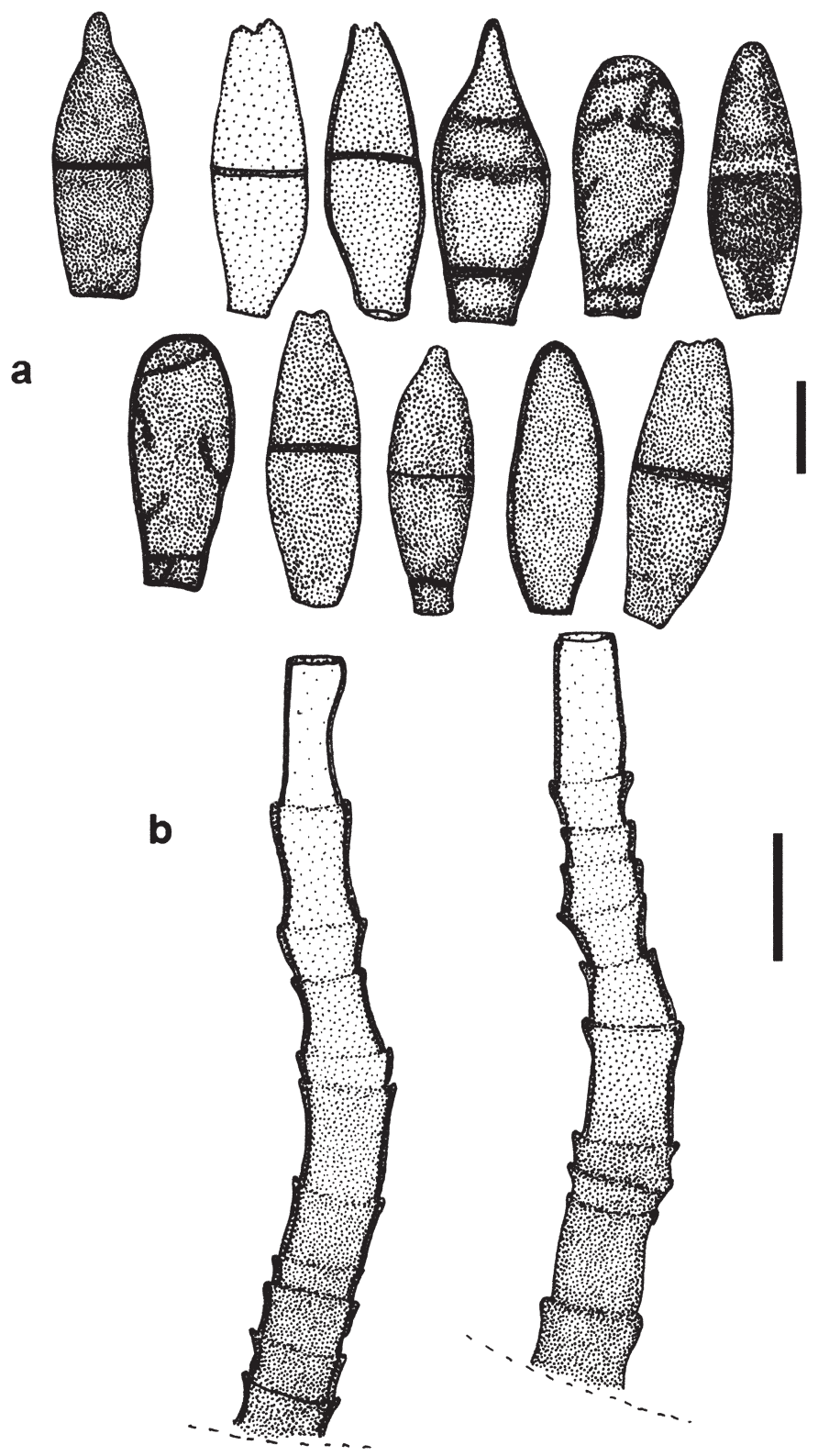

FIG. 2. Repetophragma fragile (ex holotype CBS H-20750):

a. Conidia. b. Conidiogenous cells. Bars $=10 \mu \mathrm{m}$. 

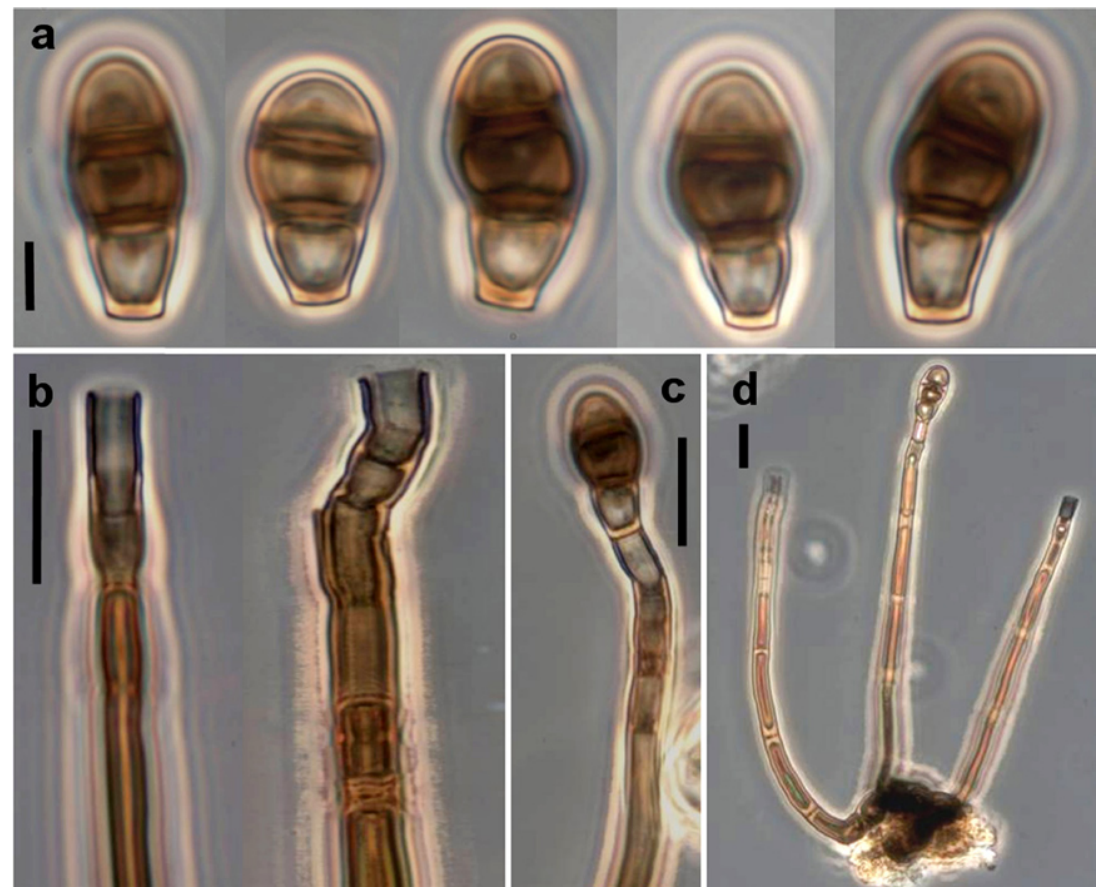

FIG. 3. Repetophragma ibericum (ex holotype HAL 2452F):

a. Conidia. b. Conidiogenous cells. c-d. Conidiophores, conidiogenous cells, and conidia. Bars $=10 \mu \mathrm{m}$.

Colonies on the natural substrate effuse, hairy, black. Mycelium superficial and immersed, composed of septate, branched, brown, smooth hyphae, 3-4 $\mu \mathrm{m}$ diam. Conidiophores distinct, single or sometimes fasciculate, unbranched, erect, straight or slightly geniculate toward the apex, 4-7-septate, with up to 7 annellations near the apex, 100-130 × 4.5-7 $\mu \mathrm{m}$, dark brown at the base and pale brown above. Conidiogenous Cells monoblastic, terminal, integrated, indeterminate, annellidic with numerous cyathiform to infundibuliform enteroblastic percurrent extensions. Conidial secession schizolytic. Conidia solitary, turbinate to globose, with broad obconical to somewhat cuneate, truncate basal cell, (1-)2(-3)-septate, dark brown at the septa, with brown to dark brown central cell and pale brown end cells, $14-18 \times 6-8 \mu \mathrm{m}$, smoothwalled, dry. Teleomorph unknown.

Repetophragma ibericum is somewhat similar to R. quadriloculare (Matsush.) R.F. Castañeda et al. (Castañeda-Ruiz et al. 2011), but the latter has larger, obovoid to subglobose, 3 -septate, smooth-walled conidia with dark brown central and basal cells, and a pale brown apical cell, $16-21 \times 8-13 \mu \mathrm{m}$, from 


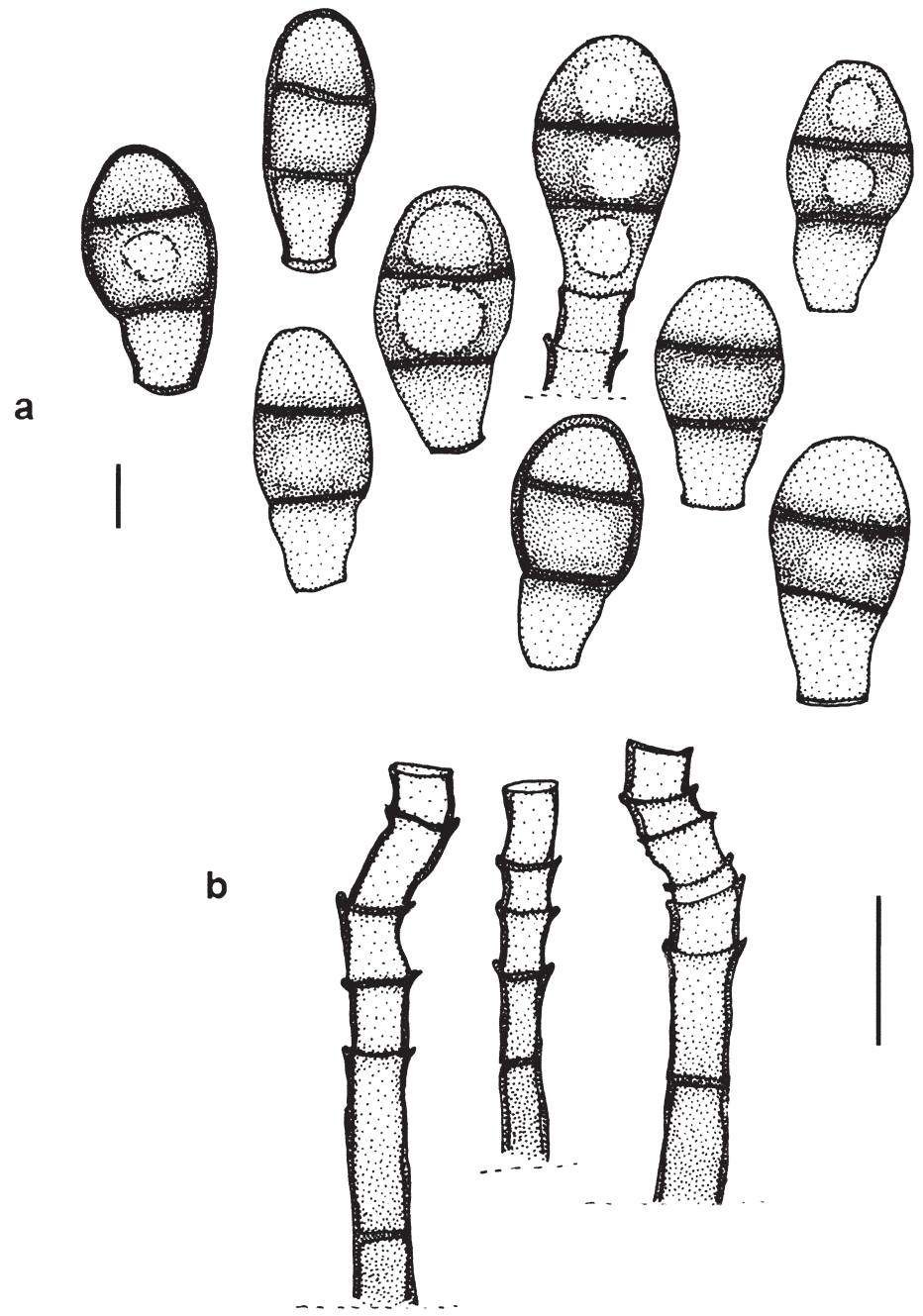

FIG. 4. Repetophragma ibericum (ex holotype HAL 2452F):

a. Conidia. b. Conidiogenous cells. Bars $=10 \mu \mathrm{m}$.

cultures on corn meal agar (conidia larger, 20-24 $\times 11-14 \mu \mathrm{m}$ on the natural substrate, according to Matsushima 1993), so the two species can be easily separated. 


\section{Acknowledgments}

The authors express their sincere gratitude to Dr De-Wei Li and Prof. Bryce Kendrick for their critical peer review of the manuscript. The authors are deeply indebted to the Spanish Ministry of "Economía y Competitividad", grant CGL 2011-27185 and the Cuban Ministry of Agriculture for facilities. We also thank Mirtha Caraballo and Beatriz Ramos for technical assistance. We acknowledge the facilities provided by Dr. P.M. Kirk and Drs. V. Robert, G. Stegehuis and A. Decock through the IndexFungorum and Mycobank websites. Dr. Lorelei L. Norvell's editorial review and Dr. Shaun Pennycook's nomenclature review are greatly appreciated.

\section{Literature cited}

Castañeda-Ruiz RF. 2005. Metodología en el estudio de los hongos anamorfos. 182-183, in: Anais do V Congresso Latino Americano de Micología. Brasilia.

Castañeda-Ruiz RF, Heredia G, Arias RM, McKenzie EHC, Hyde KD, Stadler M, Saikawa M, Gené J, Guarro J, Iturriaga T, Minter DW, Crous PW. 2011. A new species and re-disposed taxa in Repetophragma. Mycosphere 2: 273-289.

Matsushima T. 1993. Matsushima mycological memoirs 7. Kobe published by the author, $75 \mathrm{p}$.

Subramanian CV. 1992. A reassessment of Sporidesmium (hyphomycetes) and some related taxa. Proc. Indian Nat. Sci. Acad. Part B, 58: 179-190. 